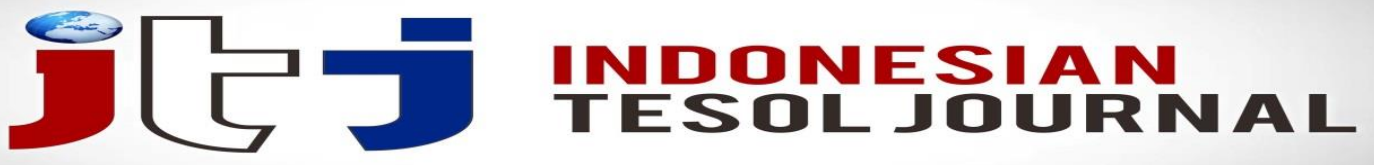

e-ISSN: 2622-5441(Online) Journal homepage: https://ejournal.iainpalopo.ac.id/index.php/ITJ/index

\title{
English as Medium of Instruction at Physics International Class Program: A Study of Students' Perception
}

\author{
Sitti Syakira \\ Universitas Siliwangi, Indonesia
}

\begin{abstract}
The specific focus of this paper is to uncover the students' perception on English language use as the medium of instruction (EMI) in the teaching and learning at Physics International Class Program (ICP), State University of Makassar. The paper describes the students' reason and expectation choosing ICP rather than regular one, their difficulties, as well as their language achievement. The data was collected using semi-structured interview to nine of third-year physical students in the program. The interviews were conducted in the language that the participant felt comfortable using (Indonesian) and recorded about seven to nine minutes each students. The analysis follows the qualitative content analysis described by Miles and Huberman, (1994): that is, themes were coded and categorized into the needs of the research, and patterns in the themes were identified and during this process, interpretations of these arrangements were made. The result of this study indicates that EMI in ICP helps some students to improve their English especially in writing, reading and vocabularies although some others are still experiencing difficulties in the teaching and learning process. Therefore, program development is still necessarily required in ICP in order to maintain its quality. Furthermore, the result of this study is expected to be a consideration for the continuity program in the future for a better service of its all aspects and to be a positive contribution for the next researcher who wants to conduct deeper research related to this topic.
\end{abstract}

Keywords: English for Academic Purpose, English as Medium of Instruction, Physics International Class Program, Students' Perception

\section{INTRODUCTION}

The fact that English is currently considered as the main international language is indisputable in all aspects of international life - trade, science, diplomacy, education and travel. In the aspect of education, Nohora \& Habte-Gabr (2008) point out that English as Foreign Language (EFL) in the classroom context plays a larger role in the development and improvement of language skill. The simultaneous learning occurs because content along with language skills are equally prioritized as opposed to other forms of instruction such as English for Specific Program (ESP) or English for Academic Purpose (EAP). In higher education of institution, the demand of this course is continuously increasing, not only in English speaking countries, but also in many countries where a number growing of higher education institutions choose EMI (Jordan, 1997; Kennedy, 2011; Hu \& Lei, 2014). $\mathrm{Hu} \&$ Lei (2014) continues that this particular approach to integrating disciplinary 
and language learning is not new but has its antecedents in several form of language education found in other educational contexts.

In Vietnamese context, EMI has been mandated in a number of Vietnam's universities as part of government's National Foreign Languages 2020 project Nguyen, Walkinshaw, \& Pham, 2017). Furthermore, in Korea, the importance of English fluency has been attracting many universities which decided to expand the use of EMI in order for students to be specialized in both certain knowledge and English (Kim, Son, \& Sohn, 2009). In Taiwan, similarly, therefore to gain a competitive edge at global higher education, Ministry of Education of Taiwan embarked promotional campaigns for EMI, and it was welcomed by many universities which began to insert EMI into the subject curricula offered in tertiary schools (Huang, 2015).

In Indonesian context, Lauder (2008) mentions that English is also increasingly used as a medium of instruction in schools and universities. Kirkpatrick (2014) assists that English remains an optional subject at primary level, and used as a Medium of Instruction (EMI) for math and science, theoretically from primary 4, but, in effect, and often from primary 1 in International Standard School, known as Sekolah Bertaraf International (SBI). However, due to the strong push from various parties in and outside education sector that schools were unprepared for EMI and teachers have low competence for that, some schools are no longer labeled as "international standard schools" although the teaching-learning activities are conducted using English (Anita, 2017).

At tertiary level, even though no specific EMI policy or rule has been implemented, larger universities have been offering this modes of delivery in their undergraduate programs — "international programs" for instance, in a private university of Indonesia, EMI policy has been introduced and implemented since the second semester of 2011/2012 academic year (Floris, 2014). In Jambi University, this international program was formerly known as International Standard Science Teacher Education (PGMIPABI) established in 2010 after the letter of DIKTI human resources director No. 2345/D4.2/2009 was issued and enacted, but stopped in 2013 due to legal action aborting the program. In the same year, the program was re-established under different name "Superior Science Teacher Education" (PGMIPA Unggulan) (Susanah, 2017). In other part of Indonesia, Yogyakarta, universities that offer EMI for undergraduate programs are Gadjah Mada University, University of Atma Jaya Yogyakarta, and University of Muhammadiyah Yogyakarta (Anita, 2017).

In East Indonesia, the State University of Makassar also applies this learning model. The establishment of International Class Program (ICP) is regarding the Act of the Republic of Indonesia No. 20 year 2003 that a national education system should ensure equal opportunity, improvement of quality and relevance and efficiency in management to meet various challenges of local, national, and global lives; therefore it requires well-planned, well-directed, and sustainable education reform. The rector of the university welcomed this International Stand ard School through Decree of Rector UNM No. 5052A/J38.H/HK/2007 by opening bilingual class on five study programs named mathematics, biology, physics, geography and chemistry education. English becomes the major medium of instruction of these 
four majors, but Bahasa Indonesia as mother tongue is still used in delivering the courses since lecturers might encounter constrains to explain the scientific concept and provide clear arguments about the principles of the concept (Hu \& Lei, 2014), and the students might confront difficulties in acquiring the specific concept in the course (Susanah, 2017). Therefore, there is still need for further research into students' attitudes towards EMI implementation, especially towards their reason and expectation choosing the ICP class, their difficulties, and their language achievement. As these aspects become the paramount significance in successful implementation of EMI in classroom, this study aims to explore how the students perceive tow ard sthe use of EMI to provide potential insight into lecturers, program, and the university.

\section{LITERATURE REVIEW}

Perceptions of EMI are evident in studies conducted in different global context. In Italia, for example, Rowland \& Murray (2019) found that both students and lecturers felt positive about the experience of EMI. In addition to this context, flexible attitude is used to encourage the students to be more comfortable with EMI and less anxious, and embrace opportunities to practice their English. However, in heterogeneous context, professional development for lecturers is still required to enable them to adjust language and content to ensure comprehensibility. In Turkish context, the lecturers convey that they support the idea that Turkish provides deeper and clearer understanding in terms of the content of the lesson, and they have no concerns related to EMI in higher education such as the resources provided in English although they agree that EMI can promote learners to be more successful in terms of both their academic and social environments and their business lives after university (Başıbek et al., 2014). Supporting this, Ekoç (2018) also concludes that the students favored English medium instruction as a result of instrumental motives no matter how challenging they assume or find it to be; however, they believe that some alterations to the way in which EMI is provided are necessary.

In Australian non-Anglophone tertiary contexts, Dang and Vu (2019) reveals untold stories of non-native English-speaking background academic about their teaching experiences of EMI. The study discovered multiple challenges facing the academics and strategies they applied to adapt English, as a mediational tool, to effectively mediate their teaching. In the other words, EMI is used as a ped agogical tool where in the implementation, they need to adapt to their students as audience and objectives of learning and teaching process. Furthermore, in Croatian academic context, the students' expectation regarding the standard of teaching performance tend s to disapprove the lecturers' proficiency (Tatzl, 2011). As for this, the lecturers in University of Rijeka have been concerned about teaching stand ard so assure the quality of EMI through a program called language development for EMI developed by Margić and Vodopija-Krstanović (2018).

In Asian context, the growing interest of EMI research follows the growing need for English as a key to global communication, relations, and information. In China, for example, Kong \& Wei (2019) who examined the learners' attitude toward EMI by a particular group of stakeholder found three major themes emerging from responses on the auxiliary questionnaire: perceived languagerelated benefits of EMI, perceived non-language-related benefits of EMI, and 
prerequisites for EMI. However, based on the sociobiographical variables (e.g. gender), the students with EMI experience scored nearly the same as the students without EMI experience. This leads EMI widely perceived as a social desideratum by students with or without EMI experience in China. Regarding the challenges in implementing EMI in the teaching-learning process, in Vietnamese context, the rapid spread of EMI does not imply success. The prerequisite for EMI - lecturers' language abilities, students' language competence and learning styles, pedagogical issues, and resources availability (Vu \& Burns, 2014) - challenges the lecturers to apply proper techniques and methods in delivering the material to encourage students' participation in the classroom. In Korean context, EMI policy is adopted with the belief that EMI would help to develop students' English skills and thus enhance their international perspective. However, a study conducted by Kim and Yoon (2018) found that EMI-class students demonstrated less level of satisfaction than the Korean Medium of Instruction (KMI)-class students although some students from both classes found EMI is helpful for developing their English ability.

The study of EMI in Indonesian education has been attracting the local researchers since the International Standards Schools was introduced although its practice has been ended now (Walker et al., 2019). The fact that Indonesian universities adopted EMI through an international class program to take advantage of global opportunities, it has been considered the solution to the problem of students' and teachers' low proficiency in the English language (Ibrahim, 2001). Baa (2018) found that even though the lecturers have limited English proficiency, lack of sufficient of bilingual materials and English environment at the campus, they are still motivated to explore more challenge materials and activities for teaching (Sultan et al., 2012), and thus the students also have benefitted in terms of confidence and fluency in English. Furthermore, EMI was generally perceived to be satisfactory to the students (Sultan et al., 2012; Zacharias, 2013; Rahmadani, 2016) although they prefer the use of Bahasa Indonesia to that of English to understand and learn the subject (Haryanto, 2012; Rowland \& Murray, 2019). The preference of local language use is in accordance with Floris (2014) who found that EMI teaching put the majority of the students into the burden when they need to respond in English. This, moreover, becomes the main concern for the university administrator who should select EMI teachers carefully since teachers in charge in such programs need both language and pedagogical competencies in explaining complicated terms and concepts in simple and clear words.

A number of educators and researchers have pointed out that students' beliefs play an important role in motivation, selection of learning strategies, and learning in general (Horwitz, 1988; Oxford, 1989; Fox, 1993; Green, 1993; McCargar, 1993; Kern, 1995; Mantle-bromley, 1995) Foreign language teachers need to keep this in mind when planning classroom activities, and that teaching activities need to be perceived in the learners' minds as conducive to learning. Therefore, following these recent studies, this paper is not to criticize or to judge the policy related to the program applied in the university where this research is conducted, but to describe the learners' perception on this EMI program called International Class Program (ICP) in terms of their reason as well as their expectation choosing the program, difficulties, and English language achievement 
at Physics International Class Program of State University of Makassar, South Sulawesi.

\section{RESEARCH METHOD}

This research took place in Physics International Class Program of State University of Makassar at the beginning of 2018/2019 academic year. It was intended to explore the students' responses towards the EMI program called ICP in the university. Having been studying for two years in the program when this research was carried out, nine students of fifth semester, 6 female and 3 males, were purposively assigned to be the participants of this research. This participant selection was, moreover, fit with their learning achievement, TOEFL score and their willingness to participate to yield information rich-case.

This study applied qualitative research design which lies on participants' viewpoints and holistic analysis on what are described in the viewpoint (Fraenkel $\&$ Wallen, 2008). The data were collected through semi-structured interview where the interviewer has a clear picture of the topic that need to be covered, but is freed to develop the topic (Heigham \& Croker, 2009). The interviews were conducted in the language that the participant felt comfortable using (Indonesian) and recorded about seven to nine minutes each student. The interview questions followed the interview protocol that was adopted from Baa (2018).

The collected data were transcribed, translated by the researcher and analyzed following the qualitative content analysis described by Miles and Huberman (1994): that is, themes were coded and categorized into the need s of the research, and patterns in the themes were identified and during this process, interpretations of these arrangements were made. To assure the response validation, the transcription and the interpretation made by the researcher were verified to the participants.

\section{FINDINGS AND DISCUSSION}

The findings of this study consist of three main points obtained from semistructured interview of nine respondents. It describes the students' reasons and expectations choosing the program and their perceptions about their English improvement and difficulties or challenges during their study in the program.

\section{Students' reason and expectation choosing ICP}

Five students admitted that they chose ICP program due to their willingness to learn both Physics and English. The following excerpts depict the students' responses toward the question.

Interviewer: Why did you choose ICP rather than regular program?

Student 1 : I chose ICP program because I love English, and I want to improve my knowledge in physics. So, in SBMPTN I chose this program because I get two benefits, studying English and Physics. 
Student 2 : I chose Physics International class program because I want to learn not only Physics, but also English. I love studying English and physics since I was in senior high school, but my parents wanted me to be in science department. So, when I found this program, I was very happy that I could fulfill both my interest and my parents' willingness.

Student 3 : When I saw this program in the website, I did not realize that it was International class program. I thought it would be very interesting learning physics while trying to improve my English when I found that.

Student 7 : I think ICP is different from another program. I like physics and English, so I was excited to learn them at the same time, and here I am now.

Student 8 : I choose international program because when I was senior high school, I loved physics so much because my teacher thought me very well, then I also liked English, so I think international program is the best way to transform my passion.

The excerpts above indicate that the students choose ICP where EMI is implemented because of their interest in learning both Physics and English. It provides them an opportunity to fulfill their interest not only in Physics but also in English. As they learn Physics theoretically and practically, they can also get new knowledge about English especially English for specific purpose and practice the knowledge they get in the field when finishing their study. Furthermore, Physics has become main object of their study, but at the same time English is a fundamental language that can make their study more challenging. This is in line with Demirbulak (2011) and Huang (2015) who also found that main reason to study at EMI program was its medium of instruction to strengthen their English ability and professional knowledge.

On the other hand, implementation of realities can have unexpected outcomes. Some responses to the interviewer's questions signpost that the students have an ideal vision of the benefits of having good English as physics students, and high expectation for the program. Another important fact revealed by their statements is that the implementation of the program does not seem to go with their expectation; they criticize their class for being still dominated by Bahasa Indonesia. Below are their responses.

Student 1 : This year, I mean recently, lecturers who used to teaching English seldom use English anymore. And as for ESM (English Subject Method), it was active in the beginning of our study, from semester 1 to 3, but now it is not. I hope it will be activated again.

Student 3 : Earlier, English was used just for 2 semesters. From then until now, it is no longer used. 
Student 4 : Sometimes, I think this program does not meet our expectation. Not all lecturers speak English, only some, and neither the students.

Regarding how the program has been implemented so far, the students seem dissatisfied with the domination of Bahasa use in the teaching and learning process despite the lecturers' ability to deliver the materials in English. Despite their admission that it is not easy learning physics through a language which is not their mother tongue, they highly expect to be in a real bilingual class, a class dominated by EMI. This EMI preference deals with Kim et al. (2009) who stated that the majority of students at Yonsei University in Korea preferred to have EMI classes only in English to improve their English at their first two year of college. Contrarily, Haryanto (2012), Kim and Yoon (2018), and Rowland and Murray (2019) in their findings related to the EMI use claim that students were favorably disposed to the use of local language in lecturers, especially in the case of difficult subjects or concepts. Supporting this, Floris (2014) added that EMI teaching put the majority of the students into the burden when they need to respond in English.

The dissatisfaction leads the students thinking that this ICP has no difference with the regular program. The student 2 said:

I think the lecturers who are teaching in ICP should have good capability, so we don't feel the same as the regular program. It seems that there is no difference between Physics ICP and regular Physics.

The statement, moreover, implies that some lecturers do not meet the requirements in terms of English language proficiency. The same study, but different major conducted in this university, verified this finding that one of the three major obstacles in the program implementation is the lecturers' low English proficiency (Vinke, Snippe, \& Jochems, 1998; Kyeyune, 2010; Manh, 2012; Vu \& Burns, 2014; Baa, 2018).

\section{Students' difficulties}

Based on the interview conducted, the students commented that studying Physics in English is very interesting since it challenges their language skill and their knowledge about the language. It is not easy to deal with specific terms (meaning, pronunciation, and the use) that they have got in the lecturing. There are some factors why it happens among the students, such as language proficiency, lack of knowledge about the language, and motivation to learn the language. Abutalebi, Cappa, and Perani (2001) conclude that language proficiency seems to be the most important factor affecting the bilingual language system. Studying bilingual (English and Indonesian) in Physics seems to be challenging enough for those students whose English does not meet the level of the subjects. And thus, it is even worse when they are not provided facilities or program that can support their learning.

Of 9 students, 5 agreed that their limitation of vocabularies becomes the major challenge in the program. One of the students commented that: 
Student 6 : Yeah, English in physics is so different from English in another subject, in another major I mean, so there are some vocabularies that are different from other subjects. This causes me difficult in learning physics.

It is important to note that by joining this program, the students are expected to familiarize certain vocabularies sustained with physics concepts that can ease them to comprehend physics-related texts. However, this expectation does not meet with the fact that lacking of vocabularies is one of the big problems for the students in this program. Another finding of the study shows that students were not fully confident in their ability to understand the knowledge concept or content related the subject due to their limitation of vocabularies (Rowland \& Murray, 2019). This verifies the finding of this study that limited knowledge and practice of daily vocabularies affect the students' English skill. The interview results of student 4 and student 8 indicate that limited vocabularies influence their understanding about the EMI courses explained by the lecturers.

In addition, the technical terms whose meaning and use are different from general words make their works even more difficult. Student 5 said that "Physics is already difficult and English makes it more difficult." Similarly, several studies conducted in different context found that the students in their study reported much language difficulty in the discursive construction of knowledge in English (Fortanet-Gómez, 2012; Ball \& Lindsay, 2013; Cots, 2013; Al-Mashikhi, AlMahrooqi, \& Denman, 2014; Hu \& Lei, 2014).

\section{Students' English language achievement}

Although, in some different contexts, students prefer L1 as medium of instruction (Haryanto, 2012; Dafouz, Camacho, \& Urquia, 2014; Floris, 2014; Kim \& Yoon, 2018; Rowland \& Murray, 2019), EMI is still perceived beneficial beyond the English-language-related gains (Sultan et al., 2012; Zacharias, 2013; Rahmadani, 2016; Kong \& Wei, 2019). In the context of this study, three main aspects of the language that, according to the students, have improved during their two years of study. The aspects are vocabulary, writing, and reading. Although some students mentioned limited vocabularies become their difficulties, two students, however, had different opinion. Student 1 and student 2 said that:

\section{Student 1 : I get new vocabulary and of course it is different from daily conversation, for example: "gaya" we say "style", but in physics we say "force".}

Student 2 : I think my vocabulary gets improved.

Student 1 and 2 think that their vocabulary gets improved during their study in ICP. The different meaning of some terms in general and specific cases make them realize that their vocabulary improves as they learn it in this program. Not only do they learn that from their lecturers, but also from the physics books they have read. It can be interpreted that they probably would not know those terms if they did not enroll in ICP. General meaning of some terms can be easily understood and used as long as we know the meaning, but the specific meaning of the 
vocabulary in ESP has to be really learnt intentionally to understand the use since it will have different meaning as it is understood from its general meaning.

The other three students explained that as they have got some tutorials in the beginning of their study, their skill in writing improves, and as their writing skill improves, their understanding of the grammar use follows. Below are their responses:

Student 3 :I think all aspects improve. But, the specific ones are probably my grammar and ability to write because they are mostly practiced in ESM (tutorial program).

Student 5 : It seems to be writing

Student 9 : Yes, it helps me improve my grammar and writing in English.

As it is known that grammar is one of the important aspects that should be considered in writing (Heaton, 1988). The understanding of grammar will help someone to construct a good or even complex sentence that describes a good writing skill. Furthermore, the tutorial that they got previously helps them in writing their task since some of their lecturers give them task in English.

Meanwhile, the other 4 students who were asked about what aspect of their English improve during their study in ICP answered that reading is the most improved skill. Their reading improves since most of references to read are in English. It motivates them to read as it is the only way they obtain information. The following are their comments:

Student 4 : It is reading because the experimental report is written in English, so we need to read more.

Student 6 : Reading. The resources are mostly in English, so I encourage myself to read more.

Student 7 : My reading skill. The program requires us to read a lot of English books.

Student 8 : Reading aspect

The finding of this session shows that EMI program gives the students contribution of their English achievement. This result is supported by HernandezNanclares and Jimenez-Munoz (2017) who found that students believe to have improved across the board, particularly their pronunciation and understanding of specialized texts or vocabularies. In addition, Sultan et al. (2012) also points out that the EMI students achieved a higher frequency of English language use, and a more positive attitude toward English and higher motivation to learn English. However, Rowland and Murray (2019) argue that EMI is more time-consuming for students in terms of reading course material and listening to lecture recordings multiple times. Therefore, the teacher's attitude to errors in English and to Italian use is quite flexible, and this appears to be a significant factor for students to feel comfortable with EMI. 


\section{CONCLUSION}

The results of the study demonstrate that the majority of students in this ICP enrolled the program just to fulfill their interest in both English and Physics. This expectation has not been fulfilled since the expectation of EMI use seems to be not implemented well. In addition, some programs that should have been conducted to support the students' learning process are not effective in its implementation due to the lack of lecturers who are able to teach in it. On the other hand, the students conveyed that lacking of vocabularies and motivation in improving their English is because of unsupported condition provided by the program. However, there are three main aspects of the language that, according to the students, have improved during their two and a half year of study which are vocabularies, writing and reading. Therefore, the result of this study suggests that program development is necessarily required in ICP in order to maintain the quality of it. The three main points discussed previously should be considered by the program stakeholder in order to provide a better atmosphere and to achieve its goal as an international class program.

This study has investigated students' perception enrolled in Physics International Class Program where English is used as the medium of instruction; thus, its results may not be applied to ICP students at other departments of ICP at UNM or in other university that apply EMI. In order to make these implication s more generalized, it will be necessary to conduct expanded studies with similar research goals, for instance, students' perception on EMI which is applied in other department at UNM and at other Indonesian universities that use EMI.

\section{REFERENCES}

Abutalebi, J., Cappa, S. F., \& Perani, D. (2001). The bilingual brain as revealed by functional neuroimaging. Bilingualism: Language and Cognition, 4(2), 179-190. https://doi.org/10.1017/s136672890100027x

Al-Mashikhi, E., Al-Mahrooqi, R., \& Denman, C. J. (2014). Investigating college of science student attitudes towards using English as a medium of instruction. The 2014 WEI International Academic Conference Proceedings, 99-113. http://www.westeastinstitute.com/wpcontent/upload s/2014/11/Christopher-Denman-EDU-Full-Paper.pdf

Anita, D. (2017). English as a Medium of Instruction in Indonesian higher education: A Study of lecturers' perception. In H. T. Nguyen, I. Walkinshaw, \& H. H. Pham (Eds.), English Medium Instruction in Higher Education in Asia-Pacific (Eds, Vol. 21, pp. 241-258). Springer International Publishing. https://d oi.org/10.1007/978-3-319-51976-0

Baa, S. (2018). Lecturer perceptions toward the teaching of Mathematics using English as a Medium of Instruction at the International Class Program (ICP) of Mathematics Department of the State University of Makassar. Journal of Physics: Conference Series, 1-5. https://doi.org/10.1088/1742$6596 / 1028 / 1 / 012131$

Ball, P., \& Lindsay, D. (2013). Language demands and support for EnglishMedium Instruction intertiary education. Learning from a specific context. In 
A. Doiz, D. Lagabastar, \& J. M. Sierra (Eds.), ENglish-Medium Instruction at Universities: Global CHallenges (Eds, pp. 44-64). Multilingual Matters.

Başıbek, N., Dolmacı, M., Cengiz, B. C., Bür, B., Dilek, Y., \& Kara, B. (2014). Lecturers' Perceptions of English Medium Instruction at Engineering Departments of Higher Education: A Study on Partial English Medium Instruction at Some State Universities in Turkey. Procedia - Social and Behavioral Sciences, 116, 1819-1825.

https://d oi.org/10.1016/j.sbspro.2014.01.477

Cots, J. M. (2013). Introducing English-Medium Instruction at the University of Lleida, Spain: Intervention, Beliefs, and Practices. In A. Doiz, D. Lagabastar, \& J. M. Sierra (Eds.), English-Medium Instruction at Universities (Eds., pp. 106-130). Multilingual Matters.

Dafouz, E., Camacho, M., \& Urquia, E. (2014). "Surely they can’t do as well": A comparison of business students' academic performance in English-medium and Spanish-as-first-language-medium programmes. Language and Education, 28(3), 223-236. https://doi.org/10.1080/09500782.2013.808661

Dang, T. K. A., \& Vu, T. T. P. (2019). English-medium instruction in the Australian higher education: untold stories of academics from non-native English-speaking backgrounds. Current Issues in Language Planning, O(0), 1-22. https://d oi.org/10.1080/14664208.2019.1641350

Demirbulak, D. (2011). A look at the Turkish and English language in Turkey from the perspectives of tertiary undergraduate students. Procedia - Social and Behavioral Sciences, 15, 4083-4088.

https://doi.org/10.1016/j.sbspro.2011.04.419

Drljača Margić, B., \& Vodopija-Krstanović, I. (2018). Language development for English-medium instruction: Teachers' perceptions, reflections and learning. Journal of English for Academic Purposes, 35, 31-41. https://doi.org/10.1016/j.jeap.2018.06.005

Ekoç, A. (2018). English Medium Instruction (EMI) from the perspectives of students at a technical university in Turkey. Journal of Further and Higher Education, 1-13. https://doi.org/10.1080/0309877X.2018.1527025

Floris, F. D. (2014). Learning subject matter through English as the medium of instruction: students' and teachers' perspectives. Asian Englishes, 16(1), 4759. https://doi.org/10.1080/13488678.2014.884879

Fortanet-Gómez, I. (2012). Academics' beliefs about language use and proficiency in Spanish multilingual higher education. AILA Review, 25, 4863. https://doi.org/10.1075/aila.25.04for

Fox, C. A. (1993). Communicative competence and beliefs about language among graduate teaching assistants in French. The Modern Language Journal, 77(3), 313-324. https://doi.org/10.2307/329100 
Fraenkel, J., \& Wallen, N. . (2008). How to Design and Evaluate Research in Education (7th Ed.). McGraw-Hill International Edition.

Green, J. M. (1993). Student attitudes toward communicative and nonCommunicative activities: Do enjoyment and effectiveness go together? The Modern Language Journal, 77(1), 1-10. https://doi.org/10.2307/329552

Haryanto, E. (2012). Listening to students voice : A survey of implementation of English as Medium of Instruction in an international stand ard school in Indonesia. Journal of Education and Practice, 3(15), 111-119. https://s3.amazonaws.com/academia.edu.documents/30312955/Listening_to_ students_voice.pdf?response-content-disposition=inline; filename=IISTE_November_Issue._High_Impact_Factor.pdf\&X-AmzAlgorithm=AWS4-HMAC-SHA256\&X-AmzCredential=AKIAIWOWYYGZ2Y53UL3A/2019

Heaton, J. B. (1988). Writing English Language Test. Longman.

Heigham, J., \& Croker, R. (2009). Qualitative Research in Applied Linguistics: A Practical Introduction (Eds). Palgrave Macmillan.

Hernandez-Nanclares, N., \& Jimenez-Munoz, A. (2017). English as a Medium of Instruction: evidence for language and content targets in bilingual education in economics. International Journal of Bilingual Education and Bilingualism, 20(7), 883-896. https://doi.org/10.1080/13670050.2015.1125847

Horwitz, E. K. (1988). The beliefs about language learning of beginning university foreign language students. The Modern Language Journal, 72, 283-294. https://doi.org/10.1111/j.1540-4781.1988.tb04190.x

Hu, G., \& Lei, J. (2014). English-Medium Instruction in Chinese higher education: A case study. Higher Education, 67(5), 551-567. https://doi.org/10.1007/s10734-013-9661-5

Huang, D.-F. (2015). Exploring and assessing effectiveness of English medium instruction courses: The students' perspectives. Procedia - Social and Behavioral Sciences, 173, 71-78. https://d oi.org/10.1016/j.sbspro.2015.02.033

Huberman, M. (1994). Qualitative Data Analysis (2nd Ed). Sage Publications.

Ibrahim, J. (2001). The implementation of EMI (English Medium Instruction) in Indonesian universities: Its opportunities, its threats, its problems, and its possible solutions. A Biannual Publication on the Study of Language and Literature, 3(2), 121-138. https://doi.org/10.9744/kata.3.2.121-138

Jordan, R. R. (1997). English for Academic Purposes (1st Eds.). Cambridge University Press.

Kennedy, C. (2011). Challenges for Language Policy, Language and 
Development. In H. Coleman (Ed.), Dreams and Realities: Developing Countries and the English Language (Eds, pp. 24-38). British Council.

Kern, R. G. (1995). Students' and teachers' beliefs about language learning. Foreign Language Annals, 28(1), 71-92. https://doi.org/10.1111/j.19449720.1995.tb00770.x

Kim, A., Son, Y. D., \& Sohn, S. Y. (2009). Conjoint analysis of enhanced English Medium Instruction for college students. Expert Systems with Applications, 36(6), 10197-10203. https://doi.org/10.1016/j.eswa.2009.01.080

Kim, E. G., \& Yoon, J. R. (2018). Korean Science and Engineering Students' Perceptions of English-Medium Instruction and Korean-Medium Instruction. Journal of Language, Identity and Education, 17(3), 182-197. https://doi.org/10.1080/15348458.2018.1433539

Kirkpatrick, A. (2014). English as a Medium of Instruction in Southeast Asian universities. In N. Murray \& A. Scarino (Eds.), Dynamic Ecologies (Eds, Vol. 9, pp. 199-214). Springer. https://doi.org/10.1007/978-94-007-7972-3

Kong, M., \& Wei, R. (2019). EFL learners' attitudes toward English-medium instruction in China: The influence of sociobiographical variables.

Linguistics and Education, 52, 44-51. https://doi.org/10.1016/j.linged.2019.03.005

Kyeyune, R. (2010). Challenges of using English as a Medium of Instruction in multilingual contexts: A View from Ugandan classrooms. Language, Culture and Curriculum, 16(2), 173-184. https://doi.org/10.1080/07908310308666666

Lauder, A. (2008). The status and function of English in Indonesia: A review of key factors. Makara Human Behavior Studies in Asia, 12(1), 9-20. https://d oi.org/10.7454/mssh.v12i1.128

Manh, L. D. (2012). English as a Medium of Instruction at tertiary education system in Vietnam. The Journal of Asia TEFL, 9(2), 97-122. https://search.proquest.com/openview/f7d32a8ff299251b161d12a4649ba2c8/ 1?pq-origsite $=$ gscholar $\& \mathrm{cbl}=4424407$

Mantle-bromley, C. (1995). Positive Attitudes and realistic beliefs : Links to proficiency. The Modern Language Journal, 79(3), 371-386. https://doi.org/10.1111/j.1540-4781.1995.tb01114.x

McCargar, D. F. (1993). Teacher and student role expectations : Differences and implications. 77(2), 192-207. https://doi.org/10.2307/328943

Nguyen, T. H., Walkinshaw, I., \& Pham, H. H. (2017). EMI programs in a Vietnamese University: Language, pedagogy and policy issues. In B. FentonSmith, I. Walkinshaw, \& P. Humphreys (Eds.), English Medium Instruction in Higher Education in Asia-Pacific (Vol. 21, pp. 37-52). Springer International Publishing. https://doi.org/10.1080/17501229.2019.1566912 
Nohora, B., \& Habte-Gabr, E. (2008). Strategies for teaching Geography electives in English to native Spanish speakers at a Colombian University. Latin American Journal of Content and Language Integrated Learning, 1(1), 1-14. https://doi.org/10.5294/laclil.2008.1.1.1

Oxford, R. L. (1989). Use of language learning strategies: A synthesis of studies with implications for strategy training. System, 17(2), 235-247. https://doi.org/10.1016/0346-251X(89)90036-5

Rahmadani, D. (2016). Students' perception of English as a Medium of Instruction (EMI) in English classroom. Journal on English as a Foreign Language, 6(2), 131. https://doi.org/10.23971/jefl.v6i2.432

Rowland, L., \& Murray, N. (2019). Finding their feet: lecturers' and students' perceptions of English as a Medium of Instruction in a recently-implemented Master's programme at an Italian university. Journal of Multilingual and Multicultural Development, O(0), 1-14. https://doi.org/10.1080/01434632.2019.1614186

Sultan, S., Borland, H., \& Eckersley, B. (2012). English Medium of Instruction (EMI) in Indonesian public junior secondary school: Students' language use, attitudes/motivation and foreign language outcomes. ACTA International TESOL COnference.

Susanah. (2017). The teaching of English in superior science classes: The congruence of students' needs and program goals. Jambi-English Language Teaching, 2(2), 40-50. http://online-journal.unja.ac.id/index.php/jelt/index

Tatzl, D. (2011). English-medium masters' programmes at an Austrian university of applied sciences: Attitudes, experiences and challenges. Journal of English for Academic Purposes, 10(4), 252-270. https://doi.org/10.1016/j.jeap.2011.08.003

Vinke, A. A., Snippe, J., \& Jochems, W. (1998). English medium content courses in non English higher education: a study of lecturer experiences and teaching behaviours. Teaching in Higher Education, 3(3), 383-394. https://d oi.org/10.1080/1356215980030307

Vu, N. T. T., \& Burns, A. (2014). English as a medium of instruction: Challenges for Vietnamese tertiary lecturers. Journal of Asia TEFL, 11(3), 1-31.

Walker, T., Liyanage, I., Madya, S., \& Hidayati, S. (2019). Media of Instruction in Indonesia: Implications for Bi/Multilingual Education. In I. Liyanage \& T. Walker (Eds.), Multilingual Education Yearbook (Eds, pp. 209-229). Springer Nature. https://doi.org/10.1007/978-3-030-14386-2_12

Zacharias, N. T. (2013). Navigating through the English-medium-of-instruction policy: Voices from the field. Current Issues in Language Planning, 14(1), 93-108. https://doi.org/10.1080/14664208.2013.782797 